\title{
HARMONIZING VOICES: FRANÇOIS LARUELLE AND ANTHONY PAUL SMITH
}

\author{
An Interview with Anthony Paul Smith (Philadelphia) \\ by Mark William Westmoreland (Villanova)
}

\begin{abstract}
The following interview of Mark William Westmoreland with Anthony Paul Smith - well-known scholar and translator of François Laruelle - considers both implications and extensions of Laruelle's non-philosophy for contemporary thought. Smith has helped bring about a surge of interest in Laruelle due to his many translations of his texts as well as being the author or co-editor of several books on Laruelle. Discussed are in particular the difficulties and joys of translating and the usefulness of Laruelle's thought for Smith's own work, especially in environmental and animal studies. Also considered are some themes of non-philosophy, the adaptability of Laruelle's thought for various disciplines, as well as new paths for Laruelle studies - new, unforeseen landscapes and uses of nonphilosophy - that explore social phenomena such as race, racism, sexism, victim a.o.
\end{abstract}

Keywords: Laruelle, translation, continental philosophy, race, ecology

Westermoreland: Thank you, Anthony, for according me this interview about François Laruelle and your own work. How did you come across Laruelle? Did you encounter his work while you were a student at DePaul or Nottingham?

Smith: I first came across Laruelle's ideas in John Ó Maoilearca's Post-Continental Philosophy: An Outline shortly after it first published by Continuum back in 2007. So, this was during my time as a student at the University of Nottingham when I was especially interested in the four thinkers of immanence that his book examines (Gilles Deleuze, Alain Badiou, Michel Henry, and of course François Laruelle). John was publishing under his Anglicized surname Mullarkey at the time, and I had found his work on Bergson incredibly 
rich and helpful for my own research (my MA examined philosophical resources in Bergson and Deleuze/Guattari for rethinking the practice of ecological restoration). In the UK, or at least at Nottingham, students are not expected to buy books for their coursework like they are in the US. The campus bookstore would just stock relatively random things, and I came across John's book there and bought it.

Westermoreland: You went to Nottingham to study alongside philosopher Philip Goodchild, correct? What drew you to Goodchild's work?

Smith: Right, I went to Nottingham to work with the Philip, whose 2002 Capitalism and Religion: The Price of Piety had changed my whole understanding of the world and philosophy. It was his work that had directed me to Deleuze and Guattari and that radical line of thinking in France and Italy centered around thinking immanence and univocity. But Nottingham was also home to a particularly pugnacious school of philosophico-theological thought known as Radical Orthodoxy which held that Deleuze was a particularly pungent example of a kind of philosophical error in turning away from transcendence that led to what they termed "nihilism." By this term they meant the decline of the West and in particular Christianity, and so astute readers and those already familiar with this school of thinking can see certain markers of white supremacist thought, specifically in a kind of highbrow European and Christian modality. Anyhow, dealing with this school of thought was in some ways really stultifying, but I have to give them credit for accurately seeing the link between ontology and politics, between being and ethics. They happen to be wrong about pretty much everything else, but there was a certain seriousness and concreteness with which philosophy and theology had to be studied in that environment that I took seriously.

Westermoreland: What was it about Ó Maoilearca's book thought caught your attention?

Smith: John's own critique of Deleuze in Post-Continental Philosophy helped me to gain some purchase on what I found dissatisfying in Deleuze's treatment of immanence, while avoiding the nostalgic draw of orthodox Christian accounts of transcendence. I think that John's critique of Deleuze was partly something he come to in his own thinking and partly through the critique of Deleuze found in Laruelle's work which in turn also dovetailed with Philip's critique. Essentially, for these three thinkers, Deleuze's understanding of immanence transposed the thought of immanence into a transcendence. This meant that 
Deleuze's philosophy was a philosophy of immanence, rather than a philosophy in or through immanence - an immanence-philosophy.

That really intrigued me and John's suggestion in Post-Continental Philosophy that both Henry's and Laruelle's philosophies offered resources to rethink immanence in an immanent way lead me to file his name in the back of my head. At the time I was an MA student and so did not have a lot of disposable income and our university library didn't have any books by Laruelle. I tried to make sense of the few incredibly difficult and contextless articles that had been translated into English, but could not really work them out at the time. My interest was piqued again when a number of us in the Philosophical Theology track at Nottingham read Ray Brassier's 2007 Nihil Unbound: Enlightenment and Extinction. While John's reading opened up a certain possibility for thinking through Laruelle's nonphilosophy, Brassier's work was all about elimination and cutting away. Something about this difference rooted in the same reading, a possibility that John had already accounted for in Post-Continental Philosophy, really intrigued me as well.

Finally I got a few of Laruelle's books and I started reading them. But it wasn't the technical aspect of immanence that first grabbed me in his thought. The first book of his I read cover to cover was Le Christ futur. Une leçon d'hérèsie. I had escaped to Paris from Nottingham for a few days and bought a used copy in Gibert Jeune. Here I found a Laruelle concerned not just with technical philosophical questions around immanence, but with suffering, with a certain gnostic hatred of the World, with an unflinching analysis of philosophy's role in constructing that world and obscuring or denying suffering, and I was moved by it all. I became somewhat obsessed with the terminology, with the syntax, and with the way of thinking. I saw in that book the performance of philosophy in immanence.

Westermoreland: You've devoted a lot of energy to working on Laruelle. What are your scholarly plans for the next year with regard to Laruelle or otherwise? Five years from now, what do you imagine yourself to be doing?

Smith: I have found Laruelle's work really helpful, but I also saw in his work a kind of escape from the way that Continental philosophy has been done in the US where we write monographs about what this French or that German philosopher's work says. I don't mean to minimize that work and I am really thankful for the strong training I received in the history of European philosophy at DePaul as an undergraduate. But it just is not what I want to do with my life. I think those of us working with Laruelle's ideas and body of work 
have done a relatively good job of avoiding setting up a journal of Laruelle Studies or the like. Laruelle has worked a lot of this out, he's discovered a certain kind of thinking, but what has always interested me, and I think what interests him, is the way that practice can be used in a variety of contexts without each page being exegesis of his books or the minutia of his archive.

So, after publishing two secondary sources on Laruelle in 2016, I want to get back to work that I think is non-philosophical but is not worried about personal fidelity to the individual François Laruelle and his interests at the level of application. As François joked in an interview that John, Marjorie Gracieuse, and I conducted with him in 2010, "Laruelle does not exist." While I am glad to know François and his incredible kindness, along with that of his partner and fellow philosopher Anne-Françoise Schmid, I think part of that kindness and part of his ethics is to refuse being a kind of "Name of the Father" that authorizes this or that orthodoxy.

In terms of my own work, I tend to think in terms of philosophical engagement with religious materials (both theological and lived) and environmental theory. So, I have two major projects that I have been working on in these two areas though I see them as interlinked. First, I want to follow-up my work in environmental philosophy with a second book that examines questions of colonialism and race in ecological thought. By ecological thought I both mean scientific thinking and what sometimes goes under the name environmental humanities or political ecology. A friend and incredible thinker named Amaryah Armstrong, who is currently finishing a PhD at Vanderbilt, read my A Non-Philosophical Theory of Nature: Ecologies of Thought (I'll never forgive the publisher for bizarrely reversing the title and subtitle) and encouraged me to engage with work being done in Black Studies around similar questions of heretical thinking, identity, the perversity of the natural, and a rejection of simplistic naturalistic thinking (which I think has nothing to do with the actual study of nature). I think that the environmental humanities trades on a reputation of radicality simply because of how distressing and catastrophic the problem of climate change is. We have all of these white scholars - and I'm one of them, and I know I don't get cookies for pointing out that my colleagues are also white - who are talking about living in the end times and rethinking the poststructuralist death of "man" without any serious engagement with ontological questions and without engaging with the important work of Katherine McKittrick, Hortense Spillers, Frank B. Wilderson, Saidiya Hartman, Jared Sexton, and others. This work is devastating to the new orthodoxies and the pretense to radical- 
ity found in the vast majority of the environmental humanities. I've laid out this charge in a long review essay of some recent books in the environmental humanities ${ }^{1}$ and I am using that criticism as a starting point for an unflinching analysis of ecological thought's antiBlackness.

The other project is an examination of theodicy as philosophical form. Again, this comes out of studying both Laruelle's work and the various projects sometimes collected under the name of Afro-pessimism. It's really important to point out that none of these thinkers are the same, they have different projects and the ways in which academia brands people or tries to stir up conflicts is even more problematic when it comes to Black scholars and how they are treated by a white supremacist academy. I am trying to work with their work as materials but with an awareness of how white scholars often appropriate and rebrand more radical work. I have no illusions that I'll ever reach the stature of these scholars and really what I am trying to do is take seriously the universal reach of Black studies that respects that the work of Black scholars is not simply a disinterested academic enterprise, as Christina Sharpe very passionately and powerfully argues in her recent In the Wake. So, I am using a kind of conjugation of this new philosophical work in Black studies with Laruelle's work to turn on the history of white European philosophy and show the ways it justifies this World and engages in various theodical forms of thinking. I've published a few historical essays on Bergson and Simone Weil that are the first fruits of this work, but the book will be less historical in scope and focused more on the form itself. I think that both Black studies and Laruelle have this core rejection of theodicy, of any justification for the world as it is, that unites them as a Gnostic form of thought which can cut through so much of the weakness and timidity of philosophical thinking today. They, and the work being undertaken by these scholars in Black studies more so than even Laruelle, gets at this connection between ontology and politics, between Being and ethics, that matters and touches on the reality of suffering in the world - of suffering the world itself.

Westermoreland: You have written that philosophy is in the midst of an identity crisis. While this is a very old concern for philosophers, might it be something we need to consider again? Has philosophy come to its end, with its questions shattered into the hands of a thousand disciplines? I certainly hope not. Perhaps it's a question of what should be done with philosophy rather than us being finished with it.

1 Online available at https://itself.blog/2017/07/06/on-the-use-and-abuse-of-objects-for-theenvironmental-humanities-recent-books-in-object-oriented-ontology-and-ecotheory/ 
Smith: We have to distinguish between the practice of thought, which can take the name philosophy, and the academic discipline siloed off with discrete problems, brands, ways bright graduate students have to sell themselves on an oversaturated market, tenure requirements, textbooks, and all the other accoutrements of intellectual life under capitalism. I think that for those who are invested in being recognizable to the contemporary academic job market as philosophers, then yes, there is a real identity crisis going on. And I don't mean to be pat at all. There are good reasons for being so invested. It's quite literally a matter of survival for many people and there are certain practices of rigor and the like that having some kind of disciplinary boundaries can engender. But I think philosophy in this catachrestic sense is about something more abiding than I hope capitalism and its abuse of our lives ends up being. For Laruelle, philosophy is not ending. It's something that manifests out of human practice. He does seek to limit or disempower the sufficiency and arrogance of philosophy, but that's not the same thing as calling for its end.

I think in his more recent work Laruelle has backed away from the more trenchant calls for philosophy's disempowerment that people took as heralding its end. For me, though, I really do think we should look for philosophical work outside of the bounds of disciplinary philosophy. That's not surprising though since my material wellbeing is not predicated on recognition as a philosopher. I'm employed as a professor in a Religion \& Theology Department and while I'm not really recognizable there either, as a discipline the study of religion has more diversity and possibility for survival in smaller niches than professional philosophers do. Still, that "luck" or whatever we might call it does allow me to see the way philosophical work takes place in scientific ecology, in politico-religious communities and their traditions of thinking, and in other less academically respectable places. That doesn't mean that philosophy has shattered into a thousand disciplines in the way some declension narratives have it, but that philosophy in the catachrestic sense is always already fractal and perverse in nature.

Westermoreland: His work tends to engage with the transcendental structures of philosophical thinking. How would you position Laruelle among his contemporaries with regard to the use of philosophy? Or, put differently, to what extent is he outside the canon?

Smith: Laruelle is very much a part of the tradition, though probably not fated to be a part of the canon. He is concerned with creating a science of philosophy and then making use of philosophy. In that way he's not so different from other French philosophers of his 
generation. Deleuze, Derrida, and Irigaray, to pick just three important examples, thought through the history of philosophy or through the philosophical texts of others. What makes Laruelle different is his stance towards this use of philosophy. Deleuze and Derrida, though perhaps not Irigaray, are concerned with extending philosophy, with reproducing philosophy, and Laruelle is concerned with its disempowerment or "degrowth" (one translation of dépotentialisation that has nice ecological connections). It's an important distinction, one that links Laruelle with more radical strands of thought.

Westermoreland: Are there aspects of Laruelle's thought that you take to be significant but haven't made their way into the secondary literature? For example, at the heart of Laruelle's work is the idea that the ordinary and generic human is something to be defended. Things like technology and politics are forms of authority that seek in some way to harass and murder the human, but which may also be disempowered by the human and used in more therapeutic modes.

Smith: Agreed. I don't think we have really worked through what his work has to add to discussions of technology and politics in relation to our existence as human beings. In some ways his work on the identity of the human is more similar to Sylvia Wynter's project than it is to his contemporaries like Foucault. Both Laruelle's and Wynter's work shows us how the construction of the false universal of Man is predicated upon a certain kind of philosophical sufficiency and where Wynter shows us the history of that project, Laruelle traces the transcendental structures of it. I think examining these transcendental structures are very important and can add to these discussions.

Westermoreland: In Ecologies of Thought, you employed Laruelle's nonphilosophy for thinking about ecology. This text might be seen, among other things, as a useful addition to environmental studies. Are there particular fields of study that you think would benefit from Laruelle's work?

Smith: Laruelle's work doesn't lend itself to imposition. I'm been pleasantly surprised by the ways he gets taken up in performance studies, visual art, and most recently in the study of Buddhism. I'd like to continue to be surprised. What Laruelle has done with his non-philosophy is create something that people can put to use in their fields, but how that ends up looking really depends on their performance of the thought. 
Westermoreland: Earlier you mentioned that you plan on writing more about questions of colonialism and race in ecological thought. The two of us have collaborated before on panels focused on colonialism, racism, and ecology, and I'm excited to see what you'll publish on this. With regard to Laruelle, do you think his work offers us anything useful for when we consider the ills of racism, sexism, homophobia, xenophobia, etc.? I'm thinking here of the French philosophical tradition of the 20th and 21st centuries with regard to race in particular. For instance, there is only one place in Ricoeur's oeuvre where race appears in an interview where Ricoeur is asked about the educational system in the United States. Balibar, however, regularly writes about race and neo-racism. Recently, Magali Bessone has published a book, Sans distinction de race?, which offers a genealogy of the concept of race, a topic that has caught on much more in the United States than in France. In short, with few exceptions, contemporary French philosophy doesn't seem that interested in questions about race and racism.

Smith: Yes, I think he does. Laruelle's work isn't really practical in the usual sense of that word and so what he offers isn't on the level of important works in anti-racist or antisexist organizing. As with all of his work he focuses at the level of the transcendental structures of our philosophical thinking. So, the ways that his work will be useful to analyzing anti-black racism or other forms of discrimination are not going to be explicit or obvious in the way that Balibar's have been, but when recognized they also won't seem added on like some of his contemporaries. What Laruelle shows is that central to philosophical thinking, to its very identity as philosophy, is a decision that operates by dividing up - or more violently, that cuts up - whatever it claims to attempt to know. This division of whatever object of knowledge is then unified by philosophy under some third term. Now this might seem to be a particularly novel claim, since many philosophers after Nietzsche (if not before) have criticized philosophy for this kind of approach. What makes Laruelle important is the acidity of his critique. He shows us that this decision is at work in philosophies who work out of a position of transcendence, like Platonism, but also transcendental philosophies, like Kant, and, more dangerously, philosophies of immanence, like Deleuze. I say acidity, because Laruelle's general critique of philosophy does not allow for us to find any refuge from the criticism. There is no "good version" of philosophy (a phrase I'm using from my friend Daniel Colucciello Barber) that is left untouched by his universal acid. It's a through-going critique of philosophy from within the male white European tradition that can be useful to rethinking the very practices of thought and refuses to constantly seek 
philosophy's innocence. It links up to certain projects, like that of the early Orlando Patterson, who showed how our conception of freedom is tied conceptually and politically to slavery. There is no conception of freedom without an absolute point of unfreedom. Laruelle tries to move beyond this kind of thinking through what he calls unilateral duality, he seeks to retool the machinery of philosophy to think in a stranger way, like showing how freedom is grounded in unfreedom and what it might look like to think from the radical immanence of that unfreedom instead.

But it is important to note that, while I think Laruelle's work is unique in this way and is useful for these sorts of projects, it doesn't mean I think he is free from error or that others couldn't or wouldn't use his work in anti-black or misogynistic ways. I could very easily see other thinkers turning to Laruelle as a renewed version of the universal image of the human that somehow "doesn't see race," whereas I see Laruelle's ethical work as being more radically tied to seeing the generic manifestation of the human in those subject positions that have historically and transcendentally been excluded or exiled from the universal. I've tried to lay this out more rigorously and thoroughly in Laruelle: A Stranger Thought. While in my short guidebook to Principles of Non-Philosophy I located Laruelle within the various European philosophical traditions he engages with, in Laruelle: A Stranger Thought I found it more interesting and fecund to show how Laruelle's work may linkup with more radical forms of thought that are generally excluded from the bounds of disciplinary philosophy.

Westermoreland: Can you explain Laruelle's concept of the victim? The victim is Laruelle's preferred example of the subject position that is, at worst excluded from or, at best, pitied by the philosophers. He lays this out most explicitly in a book-length interview translated as Intellectuals and Power and in the recent General Theory of Victims. In each case the victim is not someone to pity, the victim is not described as lacking agency, none of that. It's not really a theory of the subject position of the victim; that would be an example of the very thing that Laruelle is criticizing throughout his work where philosophy speaks about the victim rather than thinks according to the victim.

Smith: He says in General Theory of Victims that his goal is to move from the image of the victim to the concept. In that way thinking according to the victim allows Laruelle to investigate the way that world is formed philosophically. Earlier I said that Laruelle's analysis of philosophy reveals a fundamental violence that is about cutting up objects so that they, in the end, come to reflect philosophy's structures itself rather than their fundamentally immanent realness. His "victimology" is another example of that. So instead of 
thinking the victim from a position of pity, Laruelle is able to see that the way the harassment and murder of human beings, which constitutes their victimhood, also constitutes the world itself. What is it that creates a hallucination of a human being into a victim but the very need to craft a world, to create a unity of experience, to create a narrative that grounds the psychic coherence of those who persecute against those who are persecuted. Power is exactly one of the terms that Laruelle identifies as a philosophical transcendental that is used to unite terms that are separated, like victim and persecutor or victim and oppressor or even victim and criminal (which is the most reversible of relations under the so-called criminal justice system). I think there are really important works that look at that third term differently than Laruelle does, but what Laruelle aims to do is actually think the victim outside of that framework of power. Again, we can see ways in which his work is doing similar things in a different register to very powerful and radical work elsewhere. So instead of thinking how to gain power, an obsession of the disempowered Left for example, he wants to think how power might be the very term that needs to be broken with and how breaking the relation of victim and oppressor can show other modalities of subjectivity or survival within the world.

I could say quite a bit more here about how Laruelle is drawing on the gnostic ultraMaoism of the early work of Christian Jambet and Guy Lardreau, but the victim is generally a very gnostic notion in his work. The world is not something to be saved for Laruelle, only the human is. But human beings are also the very demiurge that has created that world. This is the point where I start to have some differences from Laruelle in the thinking of the victim. As with most of his work he seeks the most abstract and generic point possible. I don't think we can quite do that with victims in an easy way or at least in a way that avoids a kind of implicit liberal philosophy that obscures the further reality of the victim.

Westermoreland: We are always already conditioned by our socio-historical context, and this context, at our current conjuncture, is one marked by the ills of racism. There is a racial asymmetry that colorblindness ("doesn't see race") ignores and, consequently, perpetuates. Recall Fanon in Black Skin, White Masks, "All round me the white man [...] all this whiteness that burns me." This is sadly a white normative world.

Smith: There is a question, at the global level, of who this human demiurge that creates the world. Which particular subjects benefit from the creation of this failed world, which despite being, as Laruelle calls it, a hallucination, still has the objective power of 
death for some humans cast into these oppressed subject positions? I think it is quite clear that it has been the creation of a white world (a phrase in Fanon's Black Skin, White Masks that I am drawn to) and it benefits those subjects most who are further away from the most extreme and excluded subject positions, like the Slave and Indigenous, or the less extreme like the Foreigner. When Laruelle calls the philosopher to a position of "compassion" instead of pity in General Theory of Victims, he means a co-suffering and ultimately I think that can only look like becoming nothing in the eyes of the world.

Westermoreland: Both of the previous concerns also relate to the notion of strangers? Is there overlap in Laruelle's thinking about victims and strangers? How does the notion of stranger differ from Derrida's other or Kant's abstract universalizing of every person as an end in themselves?

Smith: There is an overlap and it's again at the level of what I have been calling the subject position of the human or the hallucination of a worldly self. The Stranger is found throughout Laruelle's earlier work and it's structurally very similar to the victim in those works. I personally like this move because it's actually a response in his thinking to what some have called the obsession with the Other in poststructuralist philosophy. As a philosophical concept the Stranger is far less obfuscatory regarding power or other means of oppression than the Other. I'm thinking here of Levinas' failure to see in the Palestinians the face of the Other in the interview where he is asked about the 1982 massacres at the Palestinian refugee camps of Sabra and Shatila or of the way in which Derrida's formulation of tout autre est tout autre can again obscure what I called the human demiurge who creates the world. The Stranger usually translates l'Étranger in Laruelle's work, but in French it also means the foreigner or alien. It's clear that Laruelle intends these meanings in his use and this gives his thinking a more concrete ethical and political character than Levinas' apolitical ethical Other does. In his work on the l'Étranger Laruelle is saying that this is the position of the foreigner that has to define any politics and any ethics, not the citizen. Again, it isn't a matter of universalizing in the sense of subtracting qualities away to get to the essence of the human, but of starting from the absolute point of deracination to think that essence. To do that one cannot simply think from some point of philosophical universalization, but one must think from a subject position even if the point is the abolition of subjects or selves in the name of the real human. 
Westermoreland: Can you shed some light on the joys and difficulties of translating Laruelle's works into English?

Smith: Translators have a really difficult job. It's impossible, really, in the best of situations. With a thinker like Laruelle there are two main difficulties. First, there is his French itself and, second, there is the way he uses terminology and ideas from across the history of philosophy without always tipping his reader off to the source or tradition he's referencing.

So, let's talk about his French first. Alex Dubilet, another translator of Laruelle's work, once told me that Laruelle read to him like a French philosopher who OD'd on German and I think that is right. French lends itself to very complex sentences generally, but Laruelle takes it up a notch in most of his books. As a translator you have a choice here and, in my view, neither of the two options are particularly great. First, you can do what Scott Davidson does in his translations of Michel Henry (who also has this Germanic style to his phenomenological writing) and either break up these French sentences into English so that they are more readable or you can leave them in their current state and risk confusion. I think Davidson's translations are great and he has good reasons for his choice, but there is also something about Laruelle's expression being an expression of radical immanence that has always made me and usually my co-translators stick to his structure. It can be a maddening experience to try and follow the grammar at times, but native French speakers report similar experiences and so if translation is about translating the experience of reading across languages then I think we're doing on ok job there. I have also tended towards more literal translations, which I think might be somewhat of a prejudice from my work in Medieval philosophy and theology where literal translations of Aquinas, Scotus, and others were more common. I think, for Laruelle, the untranslatability of a number of his jokes and cleverness gives way to privileging the ideas. I really hate missing those and try my best to find a good translation that captures them, but often they just have to be explained in a footnote and as we all know there's nothing funnier than having a joke explained to you.

Secondly, as I said, there is his use of the history of philosophy without referencing. Therefore, anyone translating Laruelle has to be well versed in the history of European philosophy, from the Ancient Greeks to 19th and 20th century German philosophy, and contemporary French philosophy as well as a smattering of work done in psychoanalysis, quantum physics, Western and Eastern Christianity, and various Gnostic philosophies and 
theologies. I'm very lucky to have received such a strong background in the history of philosophy as an undergraduate and so matching those terminology choices with standard translations or deciding to translate them a different way is weirdly enjoyable for me. I hope it makes reading Laruelle and situating his ideas within a certain constellation of ideas easier as well.

Westermoreland: Thank you again for engaging in this conversation. Do you have any final thoughts about translating?

Smith: To be honest, I find translation to be mostly heartbreaking. Either by yourself or with someone else you get to work on this massive project, devote hundreds and hundreds of hours to working through the text, move through various drafts, send it to other readers, try to incorporate their remarks or get lost on trails that go nowhere, work with copy editors of various skill levels, stare directly in the face of your own inadequacies and idiocies, work to improve over and over again, and at the end of all that hard work the best you can hope for is that it isn't a complete failure and that, if it gets read, the graduate students looking to fill up seminar time don't spend all their time nitpicking the translation choices or pointing out the errors that invariably will exist. The joys that come are intellectual in nature. Through translating I take the text on more fully than I do simply reading it. I think through it in a new way, I am writing the text myself. It isn't matter of becoming a conduit for the divine word - I'm suspicious that this is even possible - but there's a certain harmonizing of Laruelle's voice and my own. There's something joyful in that.

Dr. Anthony Paul Smith, Department of Religion,

La Salle University, smithanthony[at]lasalle.edu Dr. Mark William Westmoreland, Department of Philosophy, Villanova University, mark.westmoreland[at]villanova.edu 